\title{
A Special Issue on the cell-specific roles of mitochondrial $\mathrm{Ca}^{2+}$ handling
}

\author{
Andras Spät • Ole H. Petersen
}

Received: 29 May 2012 / Accepted: 29 May 2012 /Published online: 12 June 2012

(C) Springer-Verlag 2012

The importance of mitochondria for cellular function is universally acknowledged. It is therefore not surprising that there are plenty of excellent review articles (for example, 2) explaining the complex transport pathways that are essential for mitochondrial function. Very recently, major progress has occurred with regard to identification of the calcium influx and efflux machineries in the mitochondria [4]. The purpose of this Special Issue is - on the basis of the best and up-to-date available knowledge of the general mitochondrial characteristics - to describe and discuss the astonishing range of challenges that mitochondria face in different cell types and how these have been solved by evolution in a variety of ways.

The first three articles in this collection deal with general issues. Tullio Pozzan and his collaborators, who have done so much to reveal the physiological and pathological importance of mitochondrial $\mathrm{Ca}^{2+}$ uptake, review the latest developments in our understanding of mitochondrial $\mathrm{Ca}^{2+}$ homeostasis [12]. Damon Poburko and Nicolas Demaurex review the important topic of how the mitochondrial proton gradient is regulated by the cytosolic $\mathrm{Ca}^{2+}$ signals [13], whereas Anant Parekh and his colleagues deal with the crucially important topic of interactions between the mitochondria, the endoplasmic reticulum,

This article is published as part of the special issue on "Cell-specific roles of mitochondrial $\mathrm{Ca} 2+$ handling."

\section{A. Spät}

Department of Physiology, Semmelweiss University,

Budapest, Hungary

e-mail: Spat@eok.sote.hu

O. H. Petersen $(\bowtie)$

School of Biosciences, Cardiff University,

Museum Avenue,

Cardiff CF10 3AX Wales, UK

e-mail: PetersenOH@cardiff.ac.uk and the store-operated $\mathrm{Ca}^{2+}$ influx channels [1]. These issues are critical to the understanding of mitochondrial function in a number of specialized tissues.

The bulk of the articles in this Special Issue deal with mitochondrial functions under physiological and pathophysiological conditions in chromaffin cells [6], adrenal glomerulosa cells [14], smooth muscle cells [10], endothelial cells [8], neurons [5], pancreatic acinar cells [7, 11], hepatocytes [3], and cardiac myocytes [9]. These articles offer insights into some intriguing and partly unexpected relationships between aspects of mitochondrial function in cell types with very different functions. Thus, the ability of mitochondria to sequester $\mathrm{Ca}^{2+}$ also at low submicromolar cytosolic $\mathrm{Ca}^{2+}$ concentrations, identified in the endocrine aldosteronesecreting adrenal glomerulosa cells [14], turns out also to be of great importance for the epithelial pancreatic acinar cells, where the peripheral mitochondria only experience very modest rises in the local cytosolic $\mathrm{Ca}^{2+}$ concentration during store-operated $\mathrm{Ca}^{2+}$ entry, but nevertheless need to take up $\mathrm{Ca}^{2+}$ in order to activate the local ATP generation which is crucially needed to fuel the active $\mathrm{Ca}^{2+}$ uptake into the basal endoplasmic reticulum [11]. In stark contrast, the peripheral mitochondria in chromaffin cells experience large increases in the local cytosolic $\mathrm{Ca}^{2+}$ concentration during activation of voltage-activated $\mathrm{Ca}^{2+}$ channels, therefore only needing low-affinity mitochondrial $\mathrm{Ca}^{2+}$ uptake mechanisms [6]. Indeed, it might be undesirable - from the point of view of the physiological function of these cells - to have high-affinity mitochondrial $\mathrm{Ca}^{2+}$ uptake mechanisms. We hope that these, and many other insights into tissuespecific mitochondrial functions, will be helpful to all those interested in understanding how mitochondria can fuel the most vital processes in specialized cells, but nevertheless also play crucially important roles in a number of important disease processes. 


\section{References}

1. Bakowski D, Nelson C, Parekh AB (2012) Endoplasmic reticulummitochondria coupling: local $\mathrm{Ca}^{2+}$ signalling with functional consequences. Pflügers Arch. doi:10.1007/s00424-012-1095-x

2. Bernardi P (1999) Mitochondrial transport of cations: channels, exchangers and permeability transition. Physiol Rev 79:1127-1155

3. Das S, Hajnocky N, Antony AN, Scordas G, Gaspers LD, Clemens DL, Hoek JB, Hajnockzy G (2012) Mitochondrial morphology and dynamics in hepatocytes from normal and ethanol-fed rats. Pflügers Arch. doi:10.1007/s00424-012-1100-4

4. Drago I, Pizzo P, Pozzan T (2011) After half a century mitochondrial calcium in- and efflux machineries reveal themselves. EMBO J 30:4119-4125

5. Duchen MR (2012) Mitochondria, calcium dependent neuronal death and neurodegenerative disease. Pflügers Arch. doi:10.1007/ s00424-012-1112-0

6. Garcia-Sancho J, de Diego AMG, Garcia AG (2012) Mitochondria and chromaffin cell function. Pflügers Arch. doi:10.1007/s00424012-1074-2

7. Gerasimenko OV, Gerasimenko JV (2012) Mitochondrial function and malfunction in the pathophysiology of pancreatitis. Pflügers Arch. doi:10.1007/s00424-012-1117-8
8. Groschner LN, Waldeck-Weiermair M, Malli R, Graier W (2012) Endothelial mitochondria-less respiration more integration. Pflügers Arch. doi:10.1007/s00424-012-1085-z

9. Khan MU, Cheema Y, Shahbaz AU, Ahokas RA, Sun Y, Gerling IC, Bhattacharya SK, Weber KT (2012) Mitochondria play a central role in nonischemic cardiomyocyte necrosis: Common to acute and chronic stressor states. Pflügers Arch. doi:10.1007/ s00424-012-1079-x

10. McCarron J, Olson ML, Chalmers S (2012) Mitochondrial regulation of cytosolic $\mathrm{Ca}^{2+}$ signals in smooth muscle. Pflögers Arch. doi:10.1007/s00424-012-1108-9

11. Petersen $\mathrm{OH}$ (2012) Specific mitochondrial functions in separate sub-cellular domains of pancreatic acinar cells. Pflügers Arch. doi:10.1007/s00424-012-1099-6

12. Pizzo P, Drago I, Filadi R, Pozzan T (2012) Mitochondrial $\mathrm{Ca}^{2+}$ homeostasis: mechanisms, role and tissue specificities. Pflügers Arch. doi:10.1007/s00424-012-1122-y

13. Poburko D, Demaurex N (2012) Regulation of the mitochondrial proton gradient by cytosolic $\mathrm{Ca}^{2+}$ signals. Pflügers Arch. doi:10.1007/s00424-012-1106-y

14. Spät A, Szanda G (2012) Special features of mitochondrial $\mathrm{Ca}^{2+}$ signalling in adrenal glomerulosa cells. Pflügers Arch. doi:10.1007/ s00424-012-1086-y 